\title{
Phenotypic plasticity in sperm traits in scorpionflies (Mecoptera: Panorpidae): Consequences of larval history and seasonality on sperm length and sperm transfer
}

\author{
Andreas VERMEULEN ${ }^{1}$, Sierk ENGELS ${ }^{1}$, Leif ENGQVIST $^{1,2, *}$ and Klaus Peter SAUER ${ }^{1}$ \\ ${ }^{1}$ Department of Evolutionary Biology and Ecology, Rheinische Friedrich-Wilhelms-Universität Bonn, Germany \\ ${ }^{2}$ Theoretical Biology Group, Centre for Ecological and Evolutionary Studies, Rijksuniversiteit Groningen, The Netherlands
}

Key words. Mecoptera, Panorpidae, ejaculate expenditure, larval rearing density, spermatogenesis, sperm competition, sperm size

\begin{abstract}
We examined effects of seasonality, larval food availability and larval rearing density on sperm length, sperm transfer rates and body size in the bivoltine scorpionfly Panorpa vulgaris. Males of the first annual generation were larger and had larger sperm. Comparing individuals of two summer generations showed that adult males resulting from group bred, ad libitum fed larvae were larger but had smaller sperm than males resulting from singly kept, food deprived larvae. Thus, sperm size is not a simple function of body size. Instead, we suggest that sperm size modification was caused by varying rearing densities. Group bred individuals produced smaller sperm but transferred at higher rate. This indicates a trade-off between sperm number and sperm size as predicted by evolutionary models of sperm production. Given the strong influence of larval history in our present work, we recommend that future studies investigating the consequences of varying sperm competition risk or intensity on male gametic strategies should also control for larval history in order to avoid distorting effects.
\end{abstract}

\section{INTRODUCTION}

Since Parker (1970) developed his fundamental concept of sperm competition, the investigation of male reproductive strategies has become one of the most dynamic research fields in behavioural and evolutionary ecology. Numerous studies indicate that males of several species react adaptively in response to the risk and intensity of sperm competition by altering sperm expenditure or even morphological sperm characters as e.g. sperm size (e.g. Gage \& Barnard, 1996; Oppliger et al., 1998, 2003; Schaus \& Sakaluk, 2001; Zbinden et al., 2003; delBarcoTrillo \& Ferkin, 2004). Most of these studies, however, have focused on the impact of certain factors occurring during the adult phase such as the presence of potential rivals, and thereby left out effects from larval development (but see e.g. Gage, 1995; Stockley \& Seal, 2001; Engqvist, 2008).

There are some reasons to assume that larval history might be of particular importance. In temperate zones, short lived organisms are characterised by the necessity of seasonal timing in order to synchronize activity with favourable biotic and abiotic conditions. While larvae of univoltine organisms outlast unfavourable conditions by means of diapause and form a single annual generation, individuals of multivoltine species have to discriminate between successive seasons in order to adjust ontogenesis to the suitable mode of larval development, i.e. diapause or non-diapause development. The environmental settings are likely to differ considerably between generations (Roff, 1980; Rowe \& Ludwig, 1991) and this might influ- ence the life history of individuals and generate phenotypic plasticity in important life-history traits (Nylin \& Gotthard, 1998). Time constraints on development and the expected life span is likely to be influenced by seasonality (Roff, 1980; Nylin \& Gotthard, 1998). In contrast to non-diapause development, diapause development will be associated with the need to divide the energetic budget into energy required for hibernation as well as subsequent development and metamorphosis. Thus individuals of different generations often differ in both behaviour (e.g. Friberg \& Wiklund, 2007) and important life-history traits such as growth, size and reproductive effort (e.g. Blanckenhorn, 1994; Karlsson et al., 2008). Larvae of successive annual generations will also be confronted with different ecological conditions such as different temperature regimes or varying food availability. Hence, physiological and life history demands on hibernating and diapause-free developing larvae will differ considerably. As many empirical studies have shown that spermatogenesis in insects frequently starts in larval stages [e.g. Gassner et al., 1972 (Mecoptera); Witalis \& Godula, 1993 (Lepidoptera); Grandi, 1994 (Isoptera); Friedlander, 1997 (Lepidoptera); Carcupino et al., 1998 (Strepsiptera); Weller et al., 2001 (Lepidoptera); CepedaPalacios et al., 2001 (Diptera)], the investment in spermatogenesis is also likely to be influenced by conditions during larval development. In addition, developing males may also be sensitive to factors indicating the level of sperm competition in the adult stage. For instance, males of the Indian meal moth Plodia interpunctella spend more

\footnotetext{
* Corresponding author; Theoretical Biology Group, Centre for Ecological and Evolutionary Studies, University of Groningen,
} P.O. Box 14, NL-9750 AA Haren, The Netherlands; e-mail: L.M.Engqvist@rug.nl 
resources on sperm production at high larval breeding densities, which might be interpreted as adaptive plasticity as a reaction to a higher expected risk of sperm competition at high population densities (Gage, 1995). We therefore presume that ejaculate characteristics as e.g. sperm number or sperm size might be influenced by the developmental mode and ecological factors, such as larval food availability or breeding density.

We tested these ideas by investigating some male characters in the scorpionfly Panorpa vulgaris (Imhof \& Labram, 1836). Individuals of a $P$. vulgaris population near Freiburg (south-west Germany, $48^{\circ} \mathrm{N}, 7^{\circ} 50^{\prime} \mathrm{E}$ are bivoltine (Sauer, 1977, 1984; Sauer et al., 1986, 2003), i.e. there is a first and a second annual generation. While progeny of the first annual generation perform nondiapause development, progeny of the second annual generation have to enter diapause for hibernation. In addition, the mating system of $P$. vulgaris is characterized by high sperm competition intensity caused by polyandrous females (Sauer, 1996; Sauer et al., 1997, 1998). Sauer et al. (1997) reported very large sperm (3 to $4 \mathrm{~mm}$ ) in $P$. vulgaris. The adaptive significance of long sperm in scorpionflies is intriguing, since in several species it has been established that a male's numerical representation of sperm in the female's spermatheca strongly affects his success in sperm competition (Sauer et al., 1998; Kock et al., 2006; Engqvist et al., 2007). Thus it would seem to be more beneficial to transfer many, small sperm. It has been suggested that increased sperm size confers advantages in sperm competition (e.g. Gage, 1994; Balshine et al., 2001; Oppliger et al., 2003), even though the empirical evidence for this is highly ambiguous (see Snook, 2005; Pizzari \& Parker, 2009). Thus, although the proximate mechanisms of size-mediated benefits in sperm competition are poorly understood, sperm size might be of particular importance in $P$. vulgaris. One approach to understand the benefit of producing large sperm, is to identify under what environmental conditions sperm characteristics are changed. In the present study we have focused on the impact of seasonality and aspects of larval history on traits of adult males, namely body size, sperm size and sperm transfer rates.

\section{MATERIAL AND METHODS}

We used progeny of field caught scorpionflies for our investigations. Details concerning the breeding of scorpionflies are given in Sauer $(1970,1977)$ and Thornhill \& Sauer (1992). We used data derived from three generations for our analyses. In all generations, larvae were bred in identical climate chambers at $18^{\circ} \mathrm{C}$.

\section{Second annual generation 2001}

This experiment was originally designed to detect effects of larval food availability on sperm transfer rates. Larvae were reared under restricted food availability, i.e. they received a single segment piece of last instar Tenebrio molitor on the 1st, 9 th and 17th day, and were kept singly. After reaching the last larval stage, larvae were transferred to small, peat filled plastic tubes $(3.5 \times 8 \mathrm{~cm})$ where they finished their development. Each plastic tube contained a single larva. Adult males performed two copulations without any restriction on mating duration. In order to avoid pseudoreplication, we calculated the average value for each male.

\section{First and second annual generation 2002}

We performed this experiment to estimate the heritability of sperm transfer rates (Vermeulen et al., 2008). Sires (1st annual generation) and sons (2nd annual generation) were bred in groups of 15-20 individuals per Petri dish with food ad libitum. Pupation and metamorphosis occurred in plastic beakers or plastic cylinders, containing 12 to 60 individuals. Contrary to the second annual generation 2001, each male only performed a single copulation with mating duration restricted to $60 \mathrm{~min}$.

\section{Determining sperm transfer rates}

Matings were conducted at $18^{\circ} \mathrm{C}$ in small plastic boxes $(10 \times$ $10 \times 6 \mathrm{~cm}$ ). Moist tissue paper at the ground provided water to the scorpionflies. Following copulation females were anesthetized with $\mathrm{CO}_{2}$ and their spermatheca was dissected in a petri dish containing Ringer's solution. The spermatheca was placed in a drop of the DNA-specific fluorochrome DAPI [4', 6-diamidino-2-phenylindole; Cal Biochem $\mathrm{GmbH}$, Frankfurt, Germany; concentration $5 \mathrm{~g} / \mathrm{ml}$ Trisbuffer $(0.1$ molar, $\mathrm{pH} 7)$ ] on a glass slide and ruptured by means of needles whereby the DNA carrying regions of the sperm were stained by the fluorochrome. We added a drop of glycerine in order to avoid draining. Spermatozoa were counted using an Orthoplanfluorescence microscope (magnification $200 \times$ ).

\section{Determining sperm length}

One particular feature of Panorpa sperm is the considerable length of approximately $3.5 \mathrm{~mm}$. Due to sperm agglutination in the female's spermatheca it is almost impossible to follow the extent of a single sperm. While counting a total number of 240,840 sperm contained in 705 preparations we found a total of twenty isolated, undamaged sperm. The integrity of a single sperm can be determined by its fluorescent head region and a corkscrew-like end of the flagellum. Images of the spermatozoa were taken with an Orthoplan-fluorescence microscope, connected to a Hitachi HV-C20 camera (Diskus imaging program: C. Hilgers, Königswinter, Germany) using phase contrast microscopy. We also took a picture of an object micrometer (Lyca Wild M 420) to determine the scale of our images. Sperm and object micrometer were printed out and carefully covered with a thin thread. We measured thread length and from the inferred scale of our images, we were able to calculate real sperm size. All sperm size estimates were from different males.

\section{Statistics}

Statistical analyses were performed using SPSS 10.0. Quoted significance values are for two-tailed tests. The level of significance was set to $\mathrm{p}<0.05$. Values are given as mean \pm standard deviation.

\section{RESULTS}

\section{Effects of seasonality on male body size and sperm length}

In order to investigate whether seasonality affected male body size (measured as mean forewing length), we compared the size of sires (1st annual generation 2002) with the mean body size of sons (2nd annual generation 2002). In spite of unrestricted food supply in both generations, individuals of the spring generation were significantly larger (Table 1; Wilcoxon test: $\mathrm{Z}=-4.8 ; \mathrm{N}=31$; $\mathrm{p}$ $<0.001)$. 
TABLE 1. Comparison (mean $\pm \mathrm{SD}$ ) of sperm length, sperm transfer rate and body size of males from different generations and with different larval breeding history.

\begin{tabular}{lccc}
\hline & $\begin{array}{c}\text { 1st Generation (2002) } \\
\text { Group bred, food ad lib. }\end{array}$ & $\begin{array}{c}\text { 2nd Generation (2002) } \\
\text { Group bred, food ad lib. }\end{array}$ & $\begin{array}{c}\text { 2nd Generation }(2001) \\
\text { Singly bred, food restricted }\end{array}$ \\
\hline Sperm length $(\mathrm{mm})$ & $3.49 \pm 0.07(\mathrm{~N}=5)$ & $3.23 \pm 0.08(\mathrm{~N}=9)$ & $3.34 \pm 0.05(\mathrm{~N}=6)$ \\
Sperm transfer rate $\left(\mathrm{min}^{-1}\right)$ & $4.48 \pm 0.78(\mathrm{~N}=30)$ & $5.14 \pm 0.98(\mathrm{~N}=240)$ & $3.77 \pm 1.11(\mathrm{~N}=76)$ \\
Body size $(\mathrm{mm})$ & $13.62 \pm 0.45(\mathrm{~N}=31)$ & $12.72 \pm 0.35(\mathrm{~N}=248)$ & $12.02 \pm 0.57(\mathrm{~N}=89)$ \\
\hline
\end{tabular}

We determined sperm length of 20 isolated, undamaged spermatozoa. Five sperm stemmed from individuals of the first annual generation, the remaining sperm were transferred by individuals of the summer generations of 2001 and 2002. Sperm length ranged from 3.045 to $3.55 \mathrm{~mm}$ (Fig. 1). Similar to body size, sperm size was affected by seasonality, too (Table 1; Mann-Whitney U-test: $\mathrm{U}=0.0$, $\left.\mathrm{N}_{1}=5, \mathrm{~N}_{2}=15, \mathrm{p}<0.001\right)$.

\section{Effects of larval history on male body size and sperm length}

Comparing data of the summer generations of two successive years enabled us to detect effects of larval history on male body size and sperm length. Larval food deficiency in 2001 resulted in significantly smaller adult males compared to the ad libitum fed larvae of 2002 (Table 1; t-test: $\mathrm{t}=-11.0, \mathrm{df}=112.4, \mathrm{p}<0.001$ ). The singly bred, food deprived males of 2001 had significantly larger sperm than group bred, ad libitum fed males of 2002 (Table 1; U-test: $\mathrm{U}=6.0, \mathrm{~N}_{1}=6, \mathrm{~N}_{2}=9, \mathrm{p}=$ 0.012 ). However, comparing mean sperm size between the males of the first annual generation 2002 and summer generation 2001, the effect of seasonality still remains with animals of the spring generation producing larger spermatozoa (Table 1; U-test: $\mathrm{U}=2.0 ; \mathrm{N}_{1}=5, \mathrm{~N}_{2}=6, \mathrm{p}=$ 0.017).

\section{Effects of seasonality and larval history on sperm transfer rates}

We compared a sire's sperm transfer rate with the mean sperm transfer rate of his sons (1st and 2nd generations 2002). Again seasonality had a significant effect, whereby individuals of the second annual generation had higher sperm transfer rates (Table 1; Wilcoxon: $\mathrm{Z}=-3.4, \mathrm{~N}=$ $30, \mathrm{p}=0.001$ ).

Comparing the second annual generations of 2001 and 2002, larval history also affected sperm transfer rates. Group bred larvae with food ad libitum resulted in adult males with higher sperm transfer rates (Table 1; U-test: U $\left.=3082.5, \mathrm{~N}_{1}=76, \mathrm{~N}_{2}=240, \mathrm{p}<0.001\right)$. Thus, comparing sperm transfer rates between the two annual generations of 2002 as well as between the summer generations of 2001 and 2002 shows higher sperm transfer rates of males producing smaller sperm.

\section{DISCUSSION}

The results presented here indicate effects of seasonality on male body size and sperm length. Males of the first annual generation were larger and had larger sperm.

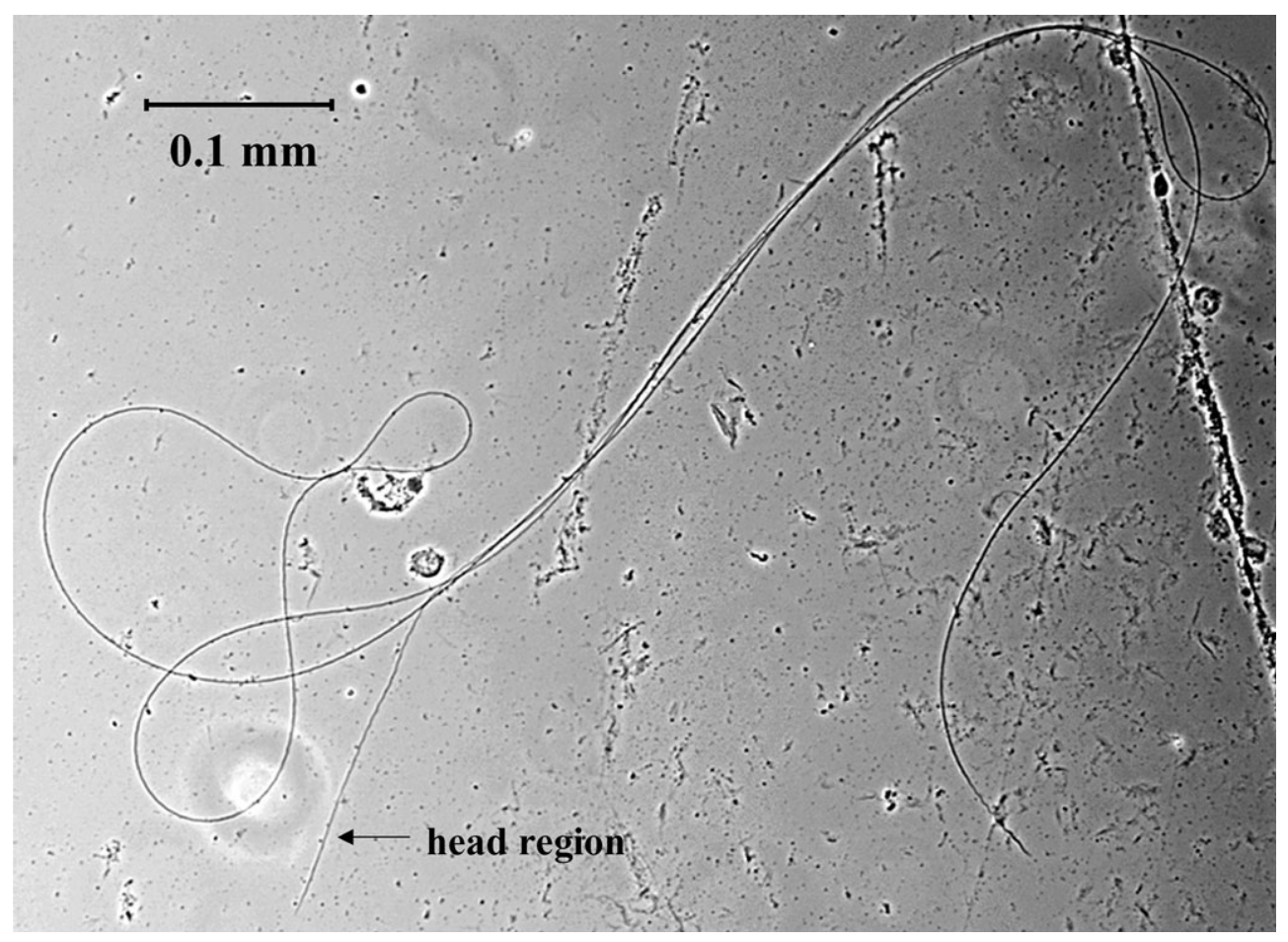

Fig. 1. Spermatozoon of $P$. vulgaris (total length: $3.55 \mathrm{~mm}$ ). 
Regarding the second annual generations of two successive years, this relationship inverts, as food deprived, singly kept larvae resulted in smaller adults with enlarged sperm. Hence, sperm size is not a simple function of body size. It is difficult to decide whether sperm length modification in the second annual generations was caused by the different modes of food supply or if larvae responded to rearing density. Only few studies examined the influence of food deficiency on sperm length. Gage \& Cook (1994) found that larval food shortage has no effect on sperm length in the moth Plodia interpunctella. Likewise Hellriegel \& Blanckenhorn (2002) demonstrated that neither larval, nor adult food availability influences sperm length in the dung fly Scathophaga stercoraria. Since it is also difficult to envisage why and how nutritional stress should lead to enlarged sperm, we suggest that sperm size reduction within the summer generation of 2002 was caused by the higher rearing density. Empirical studies provide ample evidence that sperm competition risk affects male gametic strategies in numerous species. It has been shown that males may tailor their sperm expenditure in response to for instance population density (Oppliger et al., 1998; Schaus \& Sakaluk, 2001), the presence of potential rivals (Gage, 1991; Olsson, 2001; Zbinden et al., 2003; delBarco-Trillo \& Ferkin, 2004) and female mating status (Wedell \& Cook, 1999; Martin \& Hosken, 2002; Engqvist, 2007). However, all of the above studies deal only with effects of sperm competition risk assessed during the adult phase.

A few studies (e.g. He \& Tsubaki, 1992; Gage, 1995; Stockley \& Seal, 2001; Harris \& Moore, 2005; Morrow et al., 2008; Gay et al., 2009) have demonstrated that larval rearing density also affects testis size or ejaculate characteristics in some species. These studies have consistently demonstrated that an increase in larval rearing density is associated with an increase in ejaculate investment, probably as a response to an expected risk of sperm competition during adult phase. Similar to many other insect species (Witalis \& Godula, 1993; Grandi, 1994; Friedlander, 1997; Carcupino et al., 1998; Cepeda-Palacios et al., 2001; Weller et al., 2001) sperm production in Panorpa scorpionflies starts in the prepupal stage (Gassner et al., 1972). Consequently, sperm length and possibly testis size are likely to be determined during larval development and hence, males are expected to be sensitive to signals which predict the future risk and intensity of sperm competition. Since copulation duration in 2002 was restricted to $60 \mathrm{~min}$ we cannot decide whether group breeding led to an increased number of transferred sperm, but group bred larvae transferred sperm at higher rate. Comparing sperm transfer rates between the two annual generations of 2002 as well as between the summer generations of 2001 and 2002, reveals higher sperm transfer rates of males producing smaller sperm in both cases. Grell (1942) studied the genital morphology of Panorpa and detected a sperm pump which is used for transferring the spermatozoa. Possibly, smaller sperm might be an adaptation to increase the rate of sperm transfer. On the other hand evolutionary models of sperm production predict a trade off between sperm size and sperm number (e.g. Parker, 1982, 1990a, b, 1993). Pitnick (1996) provided evidence for this kind of trade off across Drosophila species. Furthermore, Oppliger et al. (1998) demonstrated an intraspecific trade off between size and number of oligopyrene sperm in Viviparus ater. Hence, in P. vulgaris smaller sperm of group bred individuals might simply be the consequence of increased sperm production. Consistent with this argument are two studies that found that individuals reared at higher larval densities produced smaller sperm (Gage, 1995; Morrow et al., 2008; but see Gay et al., 2009).

Only recently, attention has been paid to the importance of sperm size variation (Snook, 2005). It has been suggested that larger sperm might be superior in the outcome of sperm competition. Radwan (1996) and LaMunyon \& Ward (1998) were able to show this effect in Rhizoglyphus robini and Caenorhabditis elegans, both species with amoebic and aflagellate spermatozoa. For flagellate sperm producing species evidence is rare. Some comparative studies found that sperm size is positively associated with sperm competition intensity (e.g. Gage, 1994; Balshine et al., 2001). But since these studies are purely correlative, they can only provide indirect evidence. Oppliger et al. (2003) reported that size of nonfertilizing, oligopyrene sperm influences fertilization success in Viviparus ater. Contrary in eupyrene, fertilizing sperm, size had no effect on paternity. Moreover, Morrow \& Gage (2001) and Simmons et al. (2003) demonstrated that sperm length had no effect on paternity, neither in the field cricket Gryllus bimaculatus nor in the field cricket Teleogryllus oceanicus, whereas a selective advantage for shorter sperm was found in the dung beetle Ontophagus taurus and the field cricket Gryllus bimaculatus (Gage \& Morrow, 2003; García-González \& Simmons, 2007). Furthermore, artificial selection on increased sperm competitiveness had no detectable effect on sperm size in the bean weevil Callosobruchus maculatus (Gay et al., 2009). A long sperm advantage in sperm competition for species with flagellate sperm has hitherto only been demonstrated in Drosophila melanogaster, yet only under restricted conditions affected by the morphology of the female reproductive tract (Miller \& Pitnick, 2002).

In the present study individuals of the second annual generation 2001 increased sperm size in the absence of potential rivals. Hence, sperm enlargement is unlikely to be an adaptation to sperm competition. It has long been assumed that in internally fertilizing species, where sperm can be stored for an extended time until fertilization, sperm length may be positively associated with sperm survival. The cost of producing larger sperm may therefore be counterbalanced if they enjoy higher survival and can be stored longer until fertilization (Parker, 1993, 1998). We therefore suggest that sperm length might be associated with sperm longevity in P. vulgaris. Females store sperm and produce several clutches, i.e. sperm of a single male's ejaculate can be involved in fertilizing multiple clutches. Hence, increasing sperm longevity might 
result in an increased paternity in specific situations, i.e. when long female sperm storage is particularly important. A positive correlation between sperm size and sperm longevity might thus also explain the existence of larger sperm in the first annual generation, since both, mating period and female reproductive period is prolonged in spring. A positive relationship between sperm size and longevity has been found in a bird species (Helfenstein et al., 2008). However, to our knowledge no empirical study has ever tested the relationship between sperm size and sperm longevity in insects (see also Simmons, 2001; Snook, 2005; Pizzari \& Parker, 2009). Further investigations are necessary to understand the implications of sperm length modification for the mating system of $P$. vulgaris.

Our results implicate an effect of larval rearing density and seasonality on sperm size and sperm transfer rates. Although not explicitly tested in this study, by affecting sperm size and transfer rates larval rearing conditions will most likely also affect the total number of sperm transferred. We conclude that larvae of $P$. vulgaris might be sensitive to signals which predict the future risk of sperm competition. Since initiation of spermatogenesis during larval phase is widespread, effects of larval history on male gametic strategies might be common in many species. Hence, future studies investigating the consequences of varying sperm competition risk or intensity on male gametic strategies should control for larval history in order to avoid distorting effects.

ACKNOWLEDGEMENTS. This study was supported by a grant of the Deutsche Forschungsgemeinschaft [SA 259/7-1 to $4]$.

\section{REFERENCES}

Balshine S., Leach B.J., Neat F., Werner N.Y. \& MontGOMERIE R. 2001: Sperm size of African cichlids in relation to sperm competition. Behav. Ecol. 12: 726-731.

BlANCKENHORN W.U. 1994: Fitness consequences of alternative life-histories in water striders, Aquarius remigis (Heteroptera: Gerridae). Oecologia 97: 354-366.

Carcupino M., Kathirithamby J. \& Mazzini M. 1998: Testis morphology and spermatogenesis in two species of Elenchus (Strepsiptera, Elenchidae). Int. J. Insect Morphol. Embryol. 28: 9-19.

Cepeda-Palacios R., Monroy A., Mendoza M.A. \& Scholl P.J. 2001: Testicular maturation in the sheep bot fly Oestrus ovis. Med. Vet. Entomol. 15: 275-280.

delBarco-Trillo J. \& Ferkin M.H. 2004: Male mammals respond to a risk of sperm competition conveyed by odours of conspecific males. Nature 431: 446-449.

ENGQvisT L. 2007: Male scorpionflies are able to assess the amount of rival sperm transferred by females' previous mates. Evolution 61: 1489-1494.

ENGQVIST L. 2008: Genetic variance and genotype reaction norms in response to larval food manipulation for a trait important in scorpionfly sperm competition. Funct. Ecol. 22: 127-133.

Engqvist L., Dekomien G., Lippmann T., Epplen J.T. \& Sauer K.P. 2007: Sperm transfer and paternity in the scorpionfly Panorpa cognata: large variance in traits favoured by postcopulatory episodes of sexual selection. Evol. Ecol. 21: $801-816$
Friberg M. \& WikLund C. 2007: Generation-dependent female choice: behavioural polyphenism in a bivoltine butterfly. Behav. Ecol. 18: 758-763.

FRIEDLANDER M. 1997: Control of the eupyrene-apyrene sperm dimorphism in Lepidoptera. J. Insect Physiol. 43: 1085-1092.

GAGE M.J.G. 1991: Risk of sperm competition directly affects ejaculate size in the Mediterranean fruit fly. Anim. Behav. 42: 1036-1037.

GAGE M.J.G. 1994: Associations between body-size, mating pattern, testis size and sperm length across butterflies. Proc. R. Soc. Lond. (B) 258: 247-254.

GAGE M.J.G. 1995: Continuous variation in reproductive strategy as an adaptive response to population density in the moth Plodia interpunctella. Proc. R. Soc. Lond. (B) 261: 25-30.

GAGE A.R. \& BARnARD C.J. 1996: Male crickets increase sperm number in relation to competition and female size. Behav. Ecol. Sociobiol. 38: 349-353.

GAGE M.J.G. \& CooK P.A. 1994: Sperm size or number-effects of nutritional stress upon eupyrene and apyrene sperm sperm production strategies in the moth Plodia interpunctella (Lepidoptera, Pyralidae). Funct. Ecol. 8: 594-599.

Gage M.J.G. \& Morrow E.H. 2003: Experimental evidence for the evolution of numerous, tiny sperm via sperm competition. Curr. Biol. 13: 754-757.

García-González F. \& Simmons L.W. 2007: Shorter sperm confer higher competitive fertilization success. Evolution 61: 816-824.

Gassner G., Breland O.P. \& Biesele J.J. 1972: The spermatozoa of the scorpionfly Panorpa nuptialis: a transmission electron microscope study. Ann. Entomol. Soc. Am. 65: 1302-1309.

Gay L., Hosken D.J., Vasudev R., Tregenza T. \& Eady P.E. 2009: Sperm competition and maternal effects differentially influence testis and sperm size in Callosobruchus maculatus. J. Evol. Biol. 22: 1143-1150.

Grandi G. 1994: Ovary and testis development in different stages and in the sterile caste of Kalotermes flavicollis (Fabr.) (Isoptera: Kalotermitidae). Ethol. Ecol. Evol. (Spec. Issue) 3: 17-23.

GreLl K.G. 1942: Der Genitalapparat von Panorpa communis L. Ein weiterer Beitrag zur Anatomie und Histologie der Mecopteren. Zool. Jb. Abt. Anat. Ontol. Tiere 67: 513-588.

Harris W.E. \& Moore P.J. 2005: Sperm competition and male ejaculate investment in Nauphoeta cinerea: effects of social environment during development. J. Evol. Biol. 18: 474-480.

He Y. \& Tsubaki Y. 1992: Variation in spermatophore size in the armyworm Pseudaletia separata (Lepidoptera: Noctuidae) in relation to rearing density. J. Appl. Entomol. Zool. 27: $39-45$.

Helfenstein F., Szép T., Nagy Z., Kempenaers B. \& Wagner R.H. 2008: Between-male variation in sperm size, velocity and longevity in sand martins Riparia riparia. J. Avian Biol. 39: 647-652.

Hellriegel B. \& Blanckenhorn W.U. 2002: Environmental influences on the gametic investment of yellow dung fly males. Evol. Ecol. 16: 505-522.

Karlsson B., Stjernholm F. \& Wiklund C. 2008: Test of a developmental trade-off in a polyphenic butterfly: direct development favours reproductive output. Funct. Ecol. 22: 121-126.

Kock D., Hardt C., Epplen J.T. \& Sauer K.P. 2006: Patterns of sperm use in the scorpionfly Panorpa germanica, L. (Mecoptera: Panorpidae). Behav. Ecol. Sociobiol. 60: 528-535. 
LAMunYon C.W. \& WARD S. 1998: Larger sperm outcompete smaller sperm in the nematode Caenorhabditis elegans. Proc. R. Soc. Lond. (B) 265: 1997-2002.

Martin O.Y. \& Hosken D.J. 2002: Strategic ejaculation in the common dung fly Sepsis cynipsea. Anim. Behav. 63: 541-546.

Miller G.T. \& Pitnick S. 2002: Sperm-female coevolution in Drosophila. Science 298: 1230-1233.

Morrow E.H. \& Gage M.J.G. 2001: Sperm competition experiments between lines of crickets producing different sperm lengths. Proc. R. Soc. Lond. (B) 268: 2281-2286.

Morrow E.H., Leijon A. \& Meerupati A. 2008: Hemiclonal analysis reveals significant genetic, environmental and genotype $\mathrm{x}$ environment effects on sperm size in Drosophila melanogaster. J. Evol. Biol. 21: 1692-1702.

Nylin S. \& Gotthard K. 1998. Plasticity in life-history traits. Annu. Rev. Entomol. 43: 63-83.

Olsson M. 2001: "Voyeurism" prolongs copulation in the dragon lizard Ctenophorus fordi. Behav. Ecol. Sociobiol. 50: $378-381$.

Oppliger A., Hosken D.J. \& Ribi G. 1998: Snail sperm production characteristics vary with sperm competition risk. Proc. R. Soc. Lond. (B) 265: 1527-1534.

Oppliger A., Naciri-Graven Y., Ribi G. \& Hosken D.J. 2003: Sperm length influences fertilization success during sperm competition in the snail Viviparus ater. Mol. Ecol. 12: 485-492.

PARKER G.A. 1970: Sperm competition and its evolutionary consequences in the insects. Biol. Rev. 45: 525-567.

PARKER G.A. 1982: Why are there so many tiny sperm? Sperm competition and the maintenance of two sexes. J. Theor. Biol. 96: 281-294.

PARKER G.A. 1990a: Sperm competition games: raffles and roles. Proc. R. Soc. Lond. (B) 242: 121-126.

PARKER G.A. 1990b: Sperm competition games: sneaks and extra-pair copulations. Proc. R. Soc. Lond. (B) 242: 127-133.

PARKer G.A. 1993: Sperm competition games: sperm size and sperm number under adult control. Proc. R. Soc. Lond. (B) 253: $245-254$.

PARKER G.A. 1998: Sperm competition and the evolution of ejaculates: towards a theory base. In Birkhead T.R. \& Møller A.P. (eds): Sperm Competition and Sexual Selection. Academic Press, San Diego, pp. 3-54.

PITNICK S. 1996: Investment in testes and the cost of making long sperm in Drosophila. Am. Nat. 148: 57-80.

Pizzari T. \& PARKer G.A. 2009: Sperm competition and sperm phenotype. In Birkhead T.R., Hosken D.J. \& Pitnick S. (eds): Sperm Biology: An Evolutionary Perspective. Academic Press, San Diego, pp. 207-245.

RADWAN J. 1996: Intraspecific variation in sperm competition success in the bulb mite: A role for sperm size. Proc. R. Soc Lond. (B) 263: 855-859.

RoFF D. 1980: Optimizing development time in a seasonal environment: the "ups and downs" of clinal variation. Oecologia 45: $202-208$.

Rowe L. \& LuDwIG D. 1991: Size and timing of metamorphosis in complex life cycles: time constraints and variation. Ecology 72: 413-427.

SAUER K.P. 1970: Zur Monotopbindung einheimischer Arten der Gattung Panorpa nach Untersuchungen im Freiland und Laboratorium. Zool. Jb. Abt. Syst. Ökol. Geogr. Tiere 97: 201-284.

SAUER K.P. 1977: Die adaptive Bedeutung der genetischen Variabilität der photoperiodischen Reaktion von Panorpa vulgaris. Evolutionsökologische Untersuchungen zum Einfluß des Wit- terungs- und Tageslängenverlaufs auf die Generationenfolge der Skorpionsfliegen (Mecoptera, Panorpidae). Zool. Jb. Abt. Syst. Ökol. Geogr. Tiere 104: 489-538.

SAUER K.P. 1984: The evolution of reproductive strategies as an adaptation to fluctuating environments. In Engels W. (ed.): Advances in Invertebrate Reproduction 3. Elsevier, Amsterdam, pp. 317-336.

SAUER K.P. 1996: Sexuelle Selektion und ökologische Differenzierung. J. Zool. Syst. Evol. Res. 34: 235-249.

Sauer K.P, Spieth H. \& Grüner C. 1986: Adaptive significance of genetic variability of photoperiodism in Mecoptera and Lepidoptera. In Taylor F. \& Karban R. (eds): The Evolution of Insect Life Cycles. Springer, New York, Berlin, Heidelberg, pp. 153-172.

SAuer K.P., Sindern J. \& Kall N. 1997: Nutritional status of males and sperm transfer in the scorpionfly Panorpa vulgaris (Mecoptera: Panorpidae). Entomol. Gener. 21: 189-204.

Sauer K.P., Lubjuhn T., Sindern J., Kullmann H., Kurtz J., Epplen C. \& Epplen J.T. 1998: Mating system and sexual selection in the scorpionfly Panorpa vulgaris (Mecoptera: Panorpidae). Naturwissenschaften 85: 219-228.

Sauer K.P., Vermeulen A. \& Aumann N. 2003: Temperaturedependent competition hierarchy: a mechanism stabilizing the phenological strategy in the scorpionfly Panorpa communis L. J. Zool. Syst. Evol. Res. 41: 109-117.

Schaus J.M. \& SAKaluK S.K. 2001: Ejaculate expenditures of male crickets in response to varying risk and intensity of sperm competition: not all species play games. Behav. Ecol. 12: 740-745.

Simmons L.W. 2001: Sperm Competition and its Evolutionary Consequences in the Insects. Princeton University Press, Princeton, $448 \mathrm{pp}$.

Simmons L.W., Wernham J., Garcia-Gonzalez F. \& Kamien D. 2003: Variation in paternity in the field cricket Teleogryllus oceanicus: no detectable influence of sperm numbers or sperm length. Behav. Ecol. 14: 539-545.

SNOOK R.R. 2005: Sperm in competition: not playing by the numbers. Trends Ecol. Evol. 20: 46-53.

Stockley P. \& Seal N.J. 2001: Plasticity in reproductive effort of male dung flies (Scatophaga stercoraria) as a response to larval density. Funct. Ecol. 15: 96-102.

Thornhill R. \& SAUER K.P. 1992: Genetic sire effects on the fighting ability of sons and daughters and mating success of sons in a scorpionfly. Anim. Behav. 43: 255-264.

Vermeulen A., Engels S. \& Sauer K.P. 2008: Maintenance of variance in sperm transfer rates in a scorpionfly: food availability, genetic basis and heritability. Behav. Ecol. Sociobiol. 63: 77-83.

Wedell N. \& CоOK P.A. 1999: Butterflies tailor their ejaculate in response to sperm competition risk and intensity. Proc. $R$. Soc. Lond. (B) 266: 1033-1039.

Weller J., Sun G.C., Zhou B.H., Lan Q., Hiruma K. \& RiddiFORD L.M. 2001: Isolation and developmental expression of two nuclear receptors, MHR4 and beta FTZ-F1, in the tobacco hornworm, Manduca sexta. Insect Biochem. Mol. Biol. 31: 827-837.

Witalis J. \& Godula J. 1993: Postembryonal development of the testis in cotton leaf worm, Spodoptera littoralis (Boisd.) (Noctuidae, Lepidoptera). Acta Biol. Hung. 44: 281-295.

Zbinden M., Mazzi D., Künzler R., Largiadèr C.R. \& Bakker T.C.M. 2003: Courting virtual rivals increase ejaculate size in sticklebacks (Gasterosteus aculeatus). Behav. Ecol. Sociobiol. 54: 205-213.

Received February 3, 2009; revised and accepted May 28, 2009 